\title{
An Impact Analysis of Frontline Demonstrations on Blackgram in Hadauti Region of Rajasthan, India
}

\author{
K.C. Meena ${ }^{1 *}$, B.L. Meena ${ }^{1}$, G.S. Meena ${ }^{2}$ and Hukam Singh Kothyari ${ }^{1}$ \\ ${ }^{1}$ Krishi Vigyan Kendra Sawai Madhopur, Agriculture University Kota (Raj), India \\ ${ }^{2}$ Krishi Vigyan Kendra Bundi, Agriculture University Kota (Raj), India \\ *Corresponding author
}

\begin{tabular}{l}
\hline K e y w or d s \\
Frontline \\
demonstration, \\
Blackgram production \\
technology, Yield \\
performance, Yield \\
gap, Extension gap, \\
Farmer's satisfaction, \\
Adoption, Constraints \\
\hline Article Info \\
\hline $\begin{array}{l}\text { Accepted: } \\
\text { 14 December } 2017 \\
\text { Available Online: } \\
\text { 10 January } 2018\end{array}$ \\
\hline
\end{tabular}

\section{Introduction}

Pulse crop play an important role in Indian agriculture. Their ability to use atmospheric nitrogen through biological nitrogen fixation is economically more sound and environment friendly. Pulses are grown on 23.82 million ha area with annual production of 14.66 million

\section{A B S T R A C T}

Frontline demonstration (FLD) is one of the most important and powerful tools for transfer of technology. Keeping in view of an effective extension approach of FLDs for dissemination of technology FLDs on blackgram were conducted by KVK, Anta-Baran, Rajasthan was assessed. The performance of frontline demonstrations, the extent of satisfaction level of respondent farmers over extension services and constraints in adoption blackgram production technologies that perceived by the respondents was measured in the study. The extent of adoption level was recorded under two heads like; adoption before conducting and after conducting frontline demonstration. It was observed that there was 35.71 to 48.00 percent increase in grain yield over local check and the average benefit cost ratio was higher under demonstration as compared to control plots during the all years of study. The average technology gap was $175 \mathrm{~kg} / \mathrm{ha}$ and average extension gap was $245 \mathrm{~kg} / \mathrm{ha}$ during all four years. The findings of the study also revealed that they had increase in adoption level ranging from 13.34 percent of storage and marketing to 56.19 percent of improved and quality seed after conducting the FLD programmes. The majority of the respondent farmers expressed medium $(51.43 \%)$ to the high $(33.33 \%)$ level of satisfaction for extension services and performance of technology under demonstrations. The yellow mosaic virus and other diseases, high infestation of insect-pest, non-availability of improved and quality seed, lack of knowledge about blackgram production technology and low income crop as compared to other regional crops were most important constraints in adoption of black gram production as perceived by the respondents. It can be concluded that the FLD is playing one of the important role in motivating the farmers for adoption of production technology resulting in increasing their yield and profit. 
2008 (Reddy 2009). The productivity of pulses in India continues to be quite low (622 $\mathrm{q} / \mathrm{ha}$ ) on account of several biotic and abiotic stresses besides unavailability of quality seeds of improved varieties in time and poor crop management due to unawareness and nonadoption of recommended production and plant protection technologies. India is the world's largest producer as well as consumer of black gram. It produces about 1.5 to 1.9 million tons of blackgram annually from about 3.5 million hectares of area, with an average productivity of $500 \mathrm{~kg}$ per hectare.

Frontline demonstration is one of the most important and powerful tools of extension because, in general farmers are driven by the perception that 'learning by doing' and 'Seeing is believing'. The field demonstrations conducted under the close supervision of scientists of the National Agriculture Research System is called front line demonstrations because the technologies are demonstrated for the first time by the scientists themselves before being fed in to the main extension system of the State Department of Agriculture. The main objective of front line demonstrations is to demonstrate newly released crop production and protection technologies and its management practices in the farmers' field under different agro-climatic regions and farming situations. While demonstrating the technologies in the farmers' field, the scientist are required to study the factors contributing higher crop production, field constraints of production and thereby generate production data and feedback information. Realizing the importance of FLDs in transfer of latest technologies, Krishi Vigyan Kendra have regularly been conducting FLDs on crops at farmer's field in different villages of district with the objective of convincing farmers and extension functionaries together about the production potentialities of production technologies for further wide scale diffusion. Therefore, it is very essential to demonstrate the high yielding varieties, resistant to biotic and abiotic stresses and other production technologies which the farmers generally do not adopt. Keeping in mind, the importance of FLDs on blackgram, which were conducted by the KVK, AntaBaran, Rajasthan under RKVY project entitled "Augmenting Productivity of Major Pulses of South and South-Eastern Rajasthan" during the year 2010-11 to 2014-15 were analysis under this study.

\section{Materials and Methods}

The frontline demonstrations on pulses were conducted by several institutes or organizations in Rajasthan but due to paucity of time and proximity, study was confined to FLDs conducted by KVK in Baran district of Rajasthan. For the purpose of investigation, three villages from each block (Seven) of Baran district where FLDs on blackgram were conducted under Rastriya Krishi Vikas Yojna, during preceding four years (Khairf 2011 to 2014) were selected. The data on output were collected from FLDs plots and finally the grain yield, cost of cultivation, net returns with the benefit cost ratio was work out. A comprehensive list of FLD farmers was prepared. Out of this, five beneficiaries from each selected village were randomly selected. Thus, a total sample of 105 respondents was taken for the study. The Adoption level of the farmers about improved production practices of blackgram before conducting and after conducting FLD was measured. Further, the satisfaction level of respondent farmers about extension services provided was also measured based on various dimensions like training of participating farmers, timeliness of services, supply of inputs, solving field problems and advisory services, fairness of scientists, performance of variety demonstrated and overall impact of FLDs. The data were collected through personal contacts with the help of well-structured interview 
schedule. The gathered data were processed, tabulated, classified and analyzed in terms of percent, mean percent score and ranks etc. in the light of objectives of the study. The Client Satisfaction Index was calculated as developed by Kumaran and Vijayaragavan (2005).

\section{Client Satisfaction Index $=\frac{\text { The individual obtained score }}{\text { Maximum score possible }}$}

The extension gap, technology gap and technology index was calculated by using following formulas as given by Samui et al., (2000).

Technology gap = Potential yield Demonstration yield

Extension gap $=$ Demonstration yield Farmers yield

Technology index $=\{($ Potential yield Demonstration yield) / Potential yield \} X 100

\section{Result and Discussion}

\section{Yield performance of blackgram (PU 31)}

During kharif 2011 to 2014, result of blackgram (PU-31) demonstrations conducted at farmer's field revealed that there was 35.71 to 48.00 percent increase in grain yield over local check. The table 1 shows that average yield in demonstrations varied from $740 \mathrm{~kg}$ to $920 \mathrm{~kg} / \mathrm{ha}$ during all four years and highest yield $(920 \mathrm{~kg} / \mathrm{ha})$ in demonstration was recorded during 2011 followed by 2012 (880kg/ha), 2013(760kg/ha) and 2014 (740 $\mathrm{kg} / \mathrm{ha}$ ) respectively. In local checks (Table 1), also same trend was found i.e., maximum average grain yield $(640 \mathrm{~kg} / \mathrm{ha})$ was recorded during 2011 and lowest grain yield $(500 \mathrm{~kg} / \mathrm{ha})$ was observed during 2014. The overall increase in average grain yield of blackgram
(PU-31) demonstrations was 42.35 percent over local check during all four years. It might be due the soil type and its moisture availability, rainfall and weather condition, disease and pest attacks as well as the change in the locations of demonstration plots every year. In general, in all the years grain yield of FLDs plots was higher as compared to local check which was due to good variety, seed treatment, recommended fertilizer doses, plant protection measures were followed by the demonstrators and scientists in the demonstrations plots. The similar results were also observed by Thakral and Bhatnagar (2002), Dhaka et al., (2010), and Singh (2013).

Yield gap and technology index of blackgram (PU 31)

Yield of the demonstration trails and potential yield of the crop was compared to estimate the yield gaps which were further categorized in to technology and extension gaps. The technology gap shows (Table 1) the gap in the blackgram demonstration yield over potential yield and it was maximum $(260 \mathrm{~kg} / \mathrm{ha})$ observed during kharif 2014 followed by 2013 (240kg/ha), 2012 (120kg/ha) and 2011 (80 $\mathrm{kg} / \mathrm{ha})$ respectively. The overall average technology gap was $175 \mathrm{~kg} / \mathrm{ha}$ during all four years. The observed technology gap may be attributed dissimilarity in soil fertility status, rainfall distribution, disease and pest attacks as well as the change in the locations of demonstration plots every year. Further, the maximum extension gap of $280 \mathrm{~kg} / \mathrm{ha}$ was recorded in blackgram (PU-31) demonstrations during kharif 2011 followed by $2012(260 \mathrm{~kg} / \mathrm{ha}), 2014(240 \mathrm{~kg} / \mathrm{ha})$ and 2013 (200 kg/ha) respectively (Table 1). The Overall average extension gap was $245 \mathrm{~kg} / \mathrm{ha}$ during all four years. The table 1 also revealed that the technology index varied from 8.00 to 26.00 percent and overall average technology index was 17.50 percent during all four years. 
The technology index shows the feasibility of the variety at the farmer's field. The lower value of technology index more is the feasibility of technology. This indicates that a gap existed between technology evolved and technology adoption at farmer's field. The similar results were also observed by Thakral and Bhatnagar (2002), Hiremath and Nagaraju (2009), and Dhaka et al., (2010). Hence, it can be concluded from the table 1 that increased yield was due to adoption of improved varieties and conducting demonstration of proven technologies yield potentials of crop can be increased to greater extent.

\section{Economic performance of blackgram (PU 31) FLDs}

The year wise economics of blackgram production under demonstration were estimated and the result has been presented in table 2. The economic analysis of the data over the years revealed that blackgram PU 31 FLDs recorded higher gross returns ( 33125 ), net returns (18700) and B: C ratio (2.30) as compared to local check. Further, additional cost of ` 1325 per hectare in demonstration has yielded additional net returns ' 8700 per hectare with incremental benefit cost ratio 2.30 suggesting its higher profitability and economic viability of the demonstration. The cost of cultivation increased successively of the years of study in demonstration as well as local plots.

The figures in table 2 clearly explain the significance of blackgram (PU 31) demonstration at farmer's field during four years of study in which greater net returns were obtained under demonstration plots than control. The highest net return was received in the year of 2012 ( 21800$)$ and lowest during 2013 ( 15000). The average benefit cost ratio was higher under blackgram demonstration as compared to control plots during the all years of study (Table 2). The higher net returns and $\mathrm{B}$ : $\mathrm{C}$ ratio in black gram demonstration might be due to the higher grain yield and better pricing of the produce in the market. These results in line with the findings of Gurumukhi and Mishra (2003), Hiremath and Nagaraju (2009), and Dhaka et al., (2010).

\section{Extent of adoption level of farmers}

The data regarding adoption of the improved blackgram production technologies were also recorded under two heads like; adoption before conducting and after conducting frontline demonstration. The data in table 3 revealed that the none of farmers were followed the improved practices of blackgram production like soil testing, soil treatment, seed treatment and seed rate and spacing before conducting FLDs whereas, after conducting FLDs they were adopting seed treatment (55.24 percent), soil treatment (40.95 percent), soil testing (34.29 percent) and seed rate and spacing (25.71 percent). The majority of farmers (68.57 percent) were practiced land preparation before FLDs and the remaining 31.43 percent began after FLDs. They were followed improved practices of blackgram production like; harvesting (36.19 percent), improved and quality seed (30.48 percent), sowing time and method (28.57 percent), plant protection measures (27.62 percent), weeding (24.76 percent), fertilizer application (20.00) and storage and marketing (17.14 percent) before FLDs while after conducting FLDs, farmers were other farmers were started adopting the improved practices like; weeding (44.76 percent), fertilizer application (34.29 percent), sowing time and method (23.81 percent), harvesting (20.00 percent), plant protection measures (18.09 percent), and storage and marketing (13.34 percent). The findings also revealed that they had increase in adoption ranging from 13.34 percent of storage to 56.19 percent of improved and quality seed after conducting the FLD programmes. The similar results were also reported by Meena and Gupta (2013) 
Table.1 Yield performance, yield gap and technology index of frontline demonstrations on black gram PU 31

\begin{tabular}{|c|c|c|c|c|c|c|c|c|c|}
\hline \multirow{2}{*}{$\begin{array}{c}\text { Season } \\
\text { and Year }\end{array}$} & \multirow{2}{*}{$\begin{array}{l}\text { No.of } \\
\text { Demo }\end{array}$} & \multirow{2}{*}{$\begin{array}{l}\text { Area } \\
\text { (ha) }\end{array}$} & \multicolumn{3}{|c|}{ Average Yield (Kg/ha) } & \multirow{2}{*}{$\begin{array}{l}\text { Increase in } \\
\text { Yield (\%) } \\
\text { over local }\end{array}$} & \multirow{2}{*}{$\begin{array}{l}\text { Technology } \\
\text { gap (kg/ha) }\end{array}$} & \multirow{2}{*}{$\begin{array}{l}\text { Extension } \\
\text { gap } \\
\text { (kg/ha) }\end{array}$} & \multirow{2}{*}{$\begin{array}{l}\text { Technology } \\
\text { Index }(\%)\end{array}$} \\
\hline & & & Potential & Demo. & $\begin{array}{l}\text { Local } \\
\text { Check }\end{array}$ & & & & \\
\hline $\begin{array}{c}\text { Kharif } \\
2011\end{array}$ & 50 & 20.00 & 1000 & 920 & 640 & 43.75 & 80 & 280 & 08.00 \\
\hline $\begin{array}{c}\text { Kharif } \\
2012\end{array}$ & 50 & 20.00 & 1000 & 880 & 620 & 41.94 & 120 & 260 & 12.00 \\
\hline $\begin{array}{c}\text { Kharif } \\
2013\end{array}$ & 54 & 21.60 & 1000 & 760 & 560 & 35.71 & 240 & 200 & 24.00 \\
\hline $\begin{array}{c}\text { Kharif } \\
2014\end{array}$ & 110 & 40.00 & 1000 & 740 & 500 & 48.00 & 260 & 240 & 26.00 \\
\hline Average & & & 1000 & 825 & 580 & 42.35 & 175 & 245 & 17.50 \\
\hline
\end{tabular}

Table.2 Economic performance of frontline demonstrations on black gram PU 31

\begin{tabular}{|c|c|c|c|c|c|c|c|c|c|c|}
\hline \multirow[t]{2}{*}{$\begin{array}{c}\text { Season } \\
\text { and Year }\end{array}$} & \multicolumn{2}{|c|}{$\begin{array}{l}\text { Cost of } \\
\text { cultivation } \\
\text { ( ./ha) }\end{array}$} & \multirow{2}{*}{$\begin{array}{l}\text { Additional } \\
\text { cost of } \\
\text { cultivation } \\
\text { over local } \\
\text { ( .//ha) } \\
\end{array}$} & \multicolumn{2}{|c|}{$\begin{array}{l}\text { Gross Return } \\
\text { (//ha) }\end{array}$} & \multicolumn{2}{|c|}{$\begin{array}{l}\text { Net return } \\
(\text { ( ./ha) }\end{array}$} & \multirow{2}{*}{$\begin{array}{l}\text { Additiona } \\
\text { I net } \\
\text { returns } \\
\text { over local } \\
\text { ( ./ha) }\end{array}$} & \multicolumn{2}{|c|}{$\begin{array}{l}\text { Benefit Cost } \\
\text { Ratio }\end{array}$} \\
\hline & Demo. & $\begin{array}{l}\text { Local } \\
\text { Check }\end{array}$ & & Demo. & $\begin{array}{l}\text { Local } \\
\text { Check }\end{array}$ & Demo & $\begin{array}{l}\text { Local } \\
\text { Check }\end{array}$ & & Demo. & $\begin{array}{l}\text { Local } \\
\text { Check }\end{array}$ \\
\hline $\begin{array}{c}\text { Kharif } \\
2011 \\
\end{array}$ & 11500 & 10400 & 1100 & 32200 & 22400 & 20700 & 12000 & 8700 & 2.80 & 2.15 \\
\hline $\begin{array}{c}\text { Kharif } \\
2012 \\
\end{array}$ & 11700 & 10500 & 1200 & 33500 & 23000 & 21800 & 12500 & 9300 & 2.86 & 2.19 \\
\hline $\begin{array}{c}\text { Kharif } \\
2013 \\
\end{array}$ & 17000 & 15500 & 1500 & 32000 & 23500 & 15000 & 8000 & 7000 & 1.88 & 1.52 \\
\hline $\begin{array}{c}\text { Kharif } \\
2014 \\
\end{array}$ & 17500 & 16000 & 1500 & 34800 & 23500 & 17300 & 7500 & 9800 & 1.99 & 1.47 \\
\hline Average & 14425 & 13100 & 1325 & 33125 & 23100 & 18700 & 10000 & 8700 & 2.30 & 1.76 \\
\hline
\end{tabular}

Table.3 Change in adoption level of the respondents regarding blackgram production technologies $(n=105)$

\begin{tabular}{|l|c|c|c|c|c|c|}
\hline \multirow{2}{*}{$\begin{array}{l}\text { Blackgram Production } \\
\text { Technologies }\end{array}$} & \multicolumn{3}{|c|}{ Before FLDs } & \multicolumn{2}{|c|}{ After FLDs } & \multicolumn{2}{c|}{ Increase in adoption level } \\
\hline Land preparation & 72 & Percent & No. & Percent & No. & Percent \\
\hline Soil testing & 00 & 00.57 & 105 & 100 & 33 & 31.43 \\
\hline Soil treatment & 00 & 00.00 & 36 & 34.29 & 36 & 34.29 \\
\hline Seed treatment & 00 & 00.00 & 58 & 55.24 & 58 & 40.95 \\
\hline Improved and quality seed & 32 & 30.48 & 91 & 86.67 & 59 & 56.24 \\
\hline Seed rate and spacing & 00 & 00.00 & 27 & 25.71 & 27 & 25.71 \\
\hline Sowing time and method & 30 & 28.57 & 55 & 52.38 & 25 & 23.81 \\
\hline Weeding & 26 & 24.76 & 73 & 69.52 & 47 & 44.76 \\
\hline Fertilizer application & 21 & 20.00 & 57 & 54.29 & 36 & 34.29 \\
\hline Plant protection measures & 29 & 27.62 & 48 & 45.71 & 19 & 18.09 \\
\hline Harvesting & 38 & 36.19 & 59 & 56.19 & 21 & 20.00 \\
\hline Storage and marketing & 18 & 17.14 & 32 & 30.48 & 14 & 13.34 \\
\hline
\end{tabular}


Table.4 Extent of farmer's satisfaction of extension services rendered $(\mathrm{n}=105)$

\begin{tabular}{|l|c|c|}
\hline \multicolumn{1}{|c|}{ Satisfaction level } & Number of Respondents & Percent \\
\hline Low & 16 & 15.24 \\
\hline Medium & 54 & 51.43 \\
\hline High & 35 & 33.33 \\
\hline
\end{tabular}

Table.5 Constraints faced by the farmers towards cultivation of blackgram production technologies $(n=105)$

\begin{tabular}{|l|l|c|c|}
\hline $\begin{array}{l}\text { S. } \\
\text { N }\end{array}$ & Constraints & Demonstrator (n=105) \\
\hline $\mathbf{1}$ & Lack of knowledge of black gram production technologies & MPS & Rank \\
\hline $\mathbf{2}$ & Non-availability of improved and quality seed & 72.38 & IV \\
\hline $\mathbf{3}$ & Yellow mosaic virus and other disease & 82.86 & III \\
\hline $\mathbf{4}$ & High infestation of insect-pest & 88.57 & I \\
\hline $\mathbf{5}$ & Low income as compared to regional major crops & 71.43 & II \\
\hline $\mathbf{6}$ & Shortage of labour due to MGNREGA & 57.14 & VIII \\
\hline $\mathbf{7}$ & High weed competition to the crop & 64.76 & VII \\
\hline $\mathbf{8}$ & Non-availability of reliable insecticide/fungicide & 68.57 & VI \\
\hline $\mathbf{9}$ & Crop damage by wild boar, neelgai and deers & 59.04 & IX \\
\hline
\end{tabular}

They were adopting the blackgram production technologies ranging from 25.71 percent of seed rate and spacing to 100 percent of land preparation after conducting FLD programmes. This might be due the fact that increasing in knowledge, skills and confidence level of farmers through FLD and training programmes on different production technologies of blackgram crop like; improved quality seed, seed rate and spacing, seed treatment, soil testing, soil treatment, weeding, fertilizer application, plant protection measures, and harvesting has helped farmers to improve the yield of crop.

\section{Farmer's satisfaction}

The extent of satisfaction level of respondent farmers over extension services and performance of demonstrated variety was measured by Client Satisfaction Index (CSI). It is observed from table 4 that majority of the respondent farmers expressed medium
$(51.43 \%)$ to the high $(33.33 \%)$ level of satisfaction for extension services and performance of technology under demonstrations. Only 15.24 percent of the respondents expressed lower level of satisfaction. The results are in conformity with the results of Narayanaswamy and Eshwarappa (1998), Kumaran and Vijayaragavan (2005). The medium to higher level of satisfaction with respect to services rendered, linkage with farmers, and technologies demonstrated etc. indicate stronger conviction, physical and mental involvement in the frontline demonstration which in turn would lead to higher adoption. This shows the relevance of frontline demonstration.

\section{Constraints faced by the farmers towards cultivation of blackgram}

The constraints in cultivation of blackgram that perceived by the respondents was also 
measured by researcher. The table 5 depicts that the respondent farmers expressed that yellow mosaic virus and other diseases with MPS 88.57 and assigned first rank in constraint hierarchy followed by high infestation of insect-pest (MPS 87.62), nonavailability of improved and quality seed (MPS 82.86), lack of knowledge of blackgram production technologies (MPS 72.38), low income crop as compared to other regional crops (MPS 71.43) and assigned $2^{\text {nd }}$, $3^{\text {rd }}, 4^{\text {th }}$ and $5^{\text {th }}$ rank respectively. The other important constraints perceived by the respondent farmers were non-availability of reliable insecticide/fungicide (MPS 68.57), high weed competition to the crops (MPS 64.76), shortage of labour due to MGNREGA (MPS 57.14), and crop damage by wild boar, neelgai and deers (MPS 59.04) and which assigned $6^{\text {th }}, 7^{\text {th }}, 8^{\text {th }}$ and $9^{\text {th }}$ rank respectively in problem hierarchy. The similar results were also observed by Meena and Gupta (2013) and Chattopadhyay and Mohapatra (2015).

It can be concluded that the FLD is playing one of the important role in motivating the farmers for adoption of production technology resulting in increasing their yield and profit. The farmers expressed medium to the high level of satisfaction for extension services and performance of technology under frontline demonstrations. They had increase in adoption level after conducting the FLDs. The findings of the study also concluded that yellow mosaic virus and other diseases, high infestation of insect-pest, non-availability of improved and quality seed, lack of knowledge of blackgram production technologies and low income crop as compared to other regional crops were most important constraints in cultivation of black gram crop. It can be concluded that frontline demonstration conducted under the close supervision of scientists is one of the important tool for extension to demonstrate newly released crop production and protection technologies and its management practices in the farmer's field under different agroclimatic regions and farming situations.

\section{References}

Chattopadhyay, C and Mohapatra, S D 2015. Perception of constraints in chickpea production in India Indian Journal of Agricultural Sciences, 85(2): 287-289.

Dhaka, B.L, Meena, B.S. and Suwalka, R. L. 2010. Popularization of improved maize technology through Frontline Demonstration in South-eastern Rajasthan. Journal of Agricultural Sciences, 1:39-42.

Economic Survey. 2010-11, Department of Economic Affairs, Economics Division Government of India, New Delhi, pp. 190.

Gurumukhi, D. R, and Mishra, S. 2003. Sorghum front line demonstration - A success story. Agriculture Extension Review, 15(4): 22-23.

Hiremath, S.M. and Nagaraju, M.V. 2009. Evaluation of frontline demonstration trails on onion in Haveri district of Karnataka. Karnataka J. Agri. Sci. 22(5): 1092-1093.

Kumaran, M. and Vijayaragavan, K. 2005. Farmers' satisfaction of agricultural extension services in an irrigation command area. Indian Journal Extension Education, 41(3 and 4): 8-12.

Meena, K. C., and Gupta I. N. 2013. Impact of KVK Training Programmes on Adoption of Garlic Production Technology. Journal of Krishi Vigyan Vol. 1(2): 41-43.

Narayanaswamy C, and Eshwarappa G 1998. Impact of front line demonstrations. Indian J Ext Edu, 34(1 and 2): 14-15.

Reddy, A.A. 2009. Pulses production technology: Status and way formed. Economic and Political Weekly 44 (52): 73-80. 
Samui SK, Maitra S, Roy DK, Mondal AK, Saha D 2000. Evaluation of front line demonstration on groundnut (Arachis hypogea L.) in Sundarbans. J Indian Soc Coastal Agric Res, 18(2): 180-183.

Singh, Ishwar. 2013. Impact of frontline demonstration on yield and economics of gram in Burhanpur district of MP.
Indain J. Extn. Educ. and R.D. 21:5559.

Thakral, S. K. and Bhatnagar, P. 2002. Evaluation of frontline demonstrations on Chickpea in north-western region of Haryana. Agric. Sci. Digest 22 (3):217218.

\section{How to cite this article:}

Meena, K.C., B.L. Meena, G.S. Meena and Hukam Singh Kothyari. 2018. An Impact Analysis of Frontline Demonstrations on Blackgram in Hadauti Region of Rajasthan. Int.J.Curr.Microbiol.App.Sci. 7(01): 1720-1727. doi: https://doi.org/10.20546/ijcmas.2018.701.208 